Nabchou, buying food from the Tangoutes, who consider themselves as under the rule of the governor of Sining. Twently days later the answer arrived; a messenger from the Dalai Lama, accompanied by seven officers, entreated M. Prshevalsky to return, saying that the whole population of Lassa was very excited against the strangers, as it was declared among the people that the expedition intended to steal the Dalaï-Lama himself and extirpate the Buddhist religion. A conflict with the inhabitants of Lassa being most probable, M. Prshevalsky was compelled to return. All December and January were spent on the road to Tsaïdam, the distance from Nabchou to Tsaïdam being 560 miles. Progress on this high plateau (14,000 to 16,000 feet) was very difficult; out of thirtyfour camels twenty died, and the collections were conveyed on horseback; the men mostly went on foot. We need scarcely say that the scientific collections and observations are of a great value.

On March $20 \mathrm{M}$. Prshevalsky reached the Chinese town of Sining, close to Lake Koko-nor. After having received permission from the governor of the province to go to the Hoang-ho, however, without crossing it, M. Prshevalsky sent his collections to Alashan, and went east to the banks of the Yellow River, which are fifty-six miles distant from the town of Donkyr. He reached them at the Gomi settlement. The river, 450 feet wide, and 8000 feet above the sea-level, is rapid ( 5 feet in a second). Its valley cuts deeply into a great deposit of clay, gravel, and boulders, the abrupt walls of which, along the banks of the main river, being 1600 feet high, and no less than Ioco feet along the banks of numberless tributaries. The journey across these gigantic ravines with abrupt walls (quite like those of the loess in the lower parts of the Hoang-ho) was most difficult. After a journey of 130 miles up the Hoang-ho, M. Prshevalsky reached a lofty mountain-range, which is cut through by the river, and probably is a continuation of the Burkhanbuda range. Further advance along the banks was impossible, and M. Prshevalsky not having a guide for crossing the range was compelled to return and soon reached the town Gui-doni, situated on the left bank of the Hoang-ho, forty miles below Gomi. The natural history collections from the Upper Hoang-ho are very rich : 260 species of plants, many fishes, and 500 birds. The astronomical and barometrical observations are numerous. M. Prshevalsky did not reach the sources of the Yellow River, and he supposes that they cannot be reached otherwise than along the Tibetan plateau; he doubts however that the Upper Hoang-ho makes so great a bend as it is usually shown on our maps.

The last letter from M. Prshevalsky is dated Gui-ta-din, on the Upper Hoang-ho. As is known, he returned via Alashan, and is expected at St. Petersburg by the end of January.

\section{MICHEL CHASLES}

$\mathrm{T}$ HE news of the death of Michel Chasles, perhaps the oldest and best-known mathematician in Europe, will be everywhere learned with deep regret. For the fiftyfive years over which his writings extend he has devoted himself with persistent industry to the history of geometry and to the perfection of those geometrical methods with which his name will be always associated. The "Apercu historique sur l'Origine et le Développement des Méthodes en Géométrie," which in fact forms an elaborate history of the subject from the time of Thales and Pythagoras to the beginning of the present century, is the best known of his works ; it was first published in 1837 , and a second edition appeared only a few years ago. His restoration of the Porisms of Euclid was published in 1860. The last great work of Chasles related to the investigation of the number of conics satisfying any five conditions: the special method which he invented for these researches, termed by him geometrical substitution, involved the consideration of the characteristics of systems of conics, i.e. of the numbers of conics satisfying four common conditions and (I) passing through an assumed point ; (2) touching an assumed line.

In 1865 Chasles received the Copley medal of the Royal Society; this medal has, since its foundation in 1731 , been given only five times for discoveries in pure mathematics, viz., in 1784 to Waring, in 1814 to Ivory, in 1841 to Sturm, in 1865 to Chasles, and in the present year to Sylvester.

In 1846 Chasles was appointed to fill the new Chair of Modern Geometry, founded by the Faculty of Sciences at Paris; and as a professor he exerted personal influence over the younger geometers of that time, which has since been apparent in their writings, although the effect of the geometrical methods to which he devoted his life is chiefly visible in the works of the Italian and German mathematicians. He was the inventor of the term "anharmonic ratio," but not of course of the ratio itself, which was known to the ancients. Chasles's memoirs on the attraction of ellipsoids are well known to English mathematicians and physicists; and a translation of his memoirs on Cones of the Second Order, and Spherical Conics, was published in Dublin in I 841 by Dr. Graves, now Bishop of Limerick.

Most of our readers will remember how in 1866 Chasles was deceived by $M$. Vrain Lucas by what were called the Pascal forgeries, and they will also remember how honourably be extricated himself from the matter, and did all in his power to repair the mischief done. The forger was convicted and sentenced to two years' imprisonment and not a shadow of suspicion was ever thrown upon the honour or good faith of Chasles.

Scientific visitors to Paris will miss a well-known face at the Academy and a kind and hospitable friend. Till quite recently Chasles seemed as active as ever, both mentally and physically, and it was only last September that he issued a new edition of his "Géométrie supérieure." He was a Foreign Member of the Royal Society and of the Cambridge Philosophical Society.

\section{THOMAS RYMER FONES, F.R.S.}

THE late Professor of Comparative Anatomy at King's College, London, whose death is announced, was born about the year 1820. He studied for the medical profession at Guy's Hospital, and took the diploma of the Royal College of Surgeons, London, in 1833. A chronic deafness unfitting him for the active pursuit of his profession, he devoted his attention exclusively to comparative anatomy. Some of his earliest papers were on the dissections of a tiger (Proc. Zool. Soc. 1834) and of an agouti (Proc. Zool. Soc. 1834). He was the first Professor of Comparative Anatomy at King's College, and was Fullerian Professor of Physiology to the Royal Institution in 1840. He was AssistantSecretary to the Section of Zoology and Botany during the eighth meeting of the British Association held at Newcastle-upon- Tyne in 1838 , the president of the section being Sir W. Jardine, the secretaries J. Edward Gray, Richard Owen, and John Richardson. This meeting was marked by the presence of Christian Gottfried Ehrenberg, who laid before the section a copy of his famous work, "Ueber Infusionsthierchen," making at the same time a short statement as to his views of the alimentary canal of the polygastric infusoria. These views were, in the discussion which followed, criticised by Rymer Jones, who stood almost alone among the British naturalists in opposing them. In 1838 the first part of his "General Outline of the Animal Kingdom" was published by Mr. Van Voorst, happily still among us. It was completed in ten or twelve parts, and was illustrated 
by really beautiful woodcuts. This work marked an era in the study of zoology and comparative anatomy in our country. True it is that the information of the author was mostly borrowed; true that he had no great familiarity with the work of the German naturalists of the time; true that the book will not bear to be appealed to now: but forty years ago it was the best book of its sort in England, and the generation has not as yet quite passed away which learnt from its pages. We have altered since then, both in the manner and the matter of our teaching of comparative anatomy, and for the better no doubt; but after another forty years our systems may too have seen their day. It may be conjectured that this book was in advance of its day, for an eminent writer, in reviewing it in 1839, objected to Rymer Jones' facts about the Infusoria, and declared he still placed confidence in Ehrenberg's observations, while he criticised his description of Volvox globator, and believed this "Infusorian" had nutritive organs, mouth, eyes, \&c.

Prof. R. Jones was an extensive contributor to Todd's "Cyclopædia of Anatomy and Physiology," writing no less than twelve of the articles on comparative anatomy. He was the author of at least one work on popular natural history, called the "Aquarian Naturalist." $\mathrm{He}$ was an excellent lecturer, and though never rising to the highest rank as a biologist, well deserves this passing notice in our columns.

\section{FRANK BUCKLAND}

Fir RANCIS TREVELYAN BUCKLAND was born on Dec. I7, 1826. He was the eldest son of the Very Rev. Dr. Buckland, Dean of Westminster. As a boy he was a constant companion of his father in the latter's geological excursions; he was a scholar of Winchester College and a student of Christ Church, graduating M.A. of Oxford in 1848. About this date he entered St. George's Hospital as a student of medicine, taking the diploma of the Royal College of Surgeons, London, in $185 \mathrm{I}$, becoming house surgeon to St. George's Hospital, and lastly receiving the appointment of assistant-surgeon to the 2nd Life Guards, a position he held until I863. He seems to have been always well liked in his regiment, gaining the character of a pleasant, good-natured, sociable fellow. Although fond of all that pertained to natural science, he was in no sense of the word a profound naturalist; he could seize with alacrity the popular side of a scientific question, but he seldom went deeper. Perhaps the most scientific work he ever accomplished was the editing, in 1858 , of his father's work on "Geology and Mineralogy," published as one of the Bridgewater treatises. $\mathrm{He}$ was the author of some pleasant volumes entitled "Curiosities of Natural History," was a constant writer in Land and Water, and an occasional contributor on subjects of economic zoology to the daily press. On the subjects of fish and fish-culture he was an authority, and it will be remembered that he had an interesting museum in connection with the subject at South Kensington. For his labours in this direction he received several honourable distinctions from France, and in 1869 he was appointed by the British Government one of the Inspectors of Salmon Fishing for England and Wales. He was also one of the Commissioners appointed to inquire into the $\mathrm{Crab}$ and Lobster Fisheries of this country, and the results of this Commission culminated in the useful Act regulating the oyster, crab, and lobster fisheries of the kingdom, which received the Royal assent in 1877 .

One notable event of his life was the discovery he made in 1859 of John Hunter's coffin in the vaults of St. Martin s-in-the-Fields, which was re-interred at the expense of the Royal College of Surgeons in Westminster Abbey.

Familiarly known by a large circle of friends as Frank
Buckland, he has left them while still in middl life, and it will be long ere they look upon the like of poor Frank again.

\section{NEW GUINEA ${ }^{1}$}

II.

THE various accounts of the natives given throughout these volumes leave an impression of vagueness that is very unsatisfactory. The mixture of races in various parts of New Guinea is no doubt great, but we cannot help thinking that there is a well-marked Papuan type, and that its head-quarters are in this great island. Signor D'Albertis seems to attach too much importance to minor peculiarities. He continually mentions small differences in the features, the hair, the form of the skull, or the stature, as implying a radical difference of race, forgetting that such differences are found among every people and in every country, and that on this principle we might establish a dozen different "races" in Europe. Taking the term Papuan in a broad sense as including all the dark-skinned woolly or crisp-haired tribes of the Western Pacific, it seems clear that New Guinea is very largely peopled by this race, and that its north-western peninsulas contain the most typical examples of it. In the south-east however another race is found which may be described as yellow-skinned and smooth-haired, and these are clearly Polynesians or "Mahori," that is of the same race as the natives of Samoa and New Zealand. In the Fly River and adjacent country both these occur, as well as a mixed race, which D'Albertis seems to think is destined to sup. plant them. He describes these races as follows :-

"The two varieties to which I allude may be defined thus: the yellow, and the black. The term yellow does not exactly express the first, nor does black the second, and those adjectives must be used comparatively only. The characteristics of the yellow variety are as follows:hair curling or smooth-neither crisp nor woolly, black and shining, often almost of a chestnut hue; forehead large and flat; temples little, if at all depressed; eye orbits scarcely, if at all, prominent; cheek-bones rather high; round chin and round face; large brown eyes, with eyeballs of a bluish-white; the nose often aquiline, never flattened, and generally small; lips moderately full; and brachycephalous and round skull. These people are not prognathous. In colour they vary from brown to very light brownish yellow. In stature they are not generally inferior to the black race, and their forms are fuller and rounder.

"The black variety is distinguished by a narrow and retreating forehead, compressed temples, strongly-marked orbital arches, prominent cheek-bones, aquiline nose, pointed and narrow chin, long face, decidedly prognathous, an oblong skull. The eves are small, either black or brown, the eyeball bloodshot or yellowish, and the men are tall and generally thin. The preponderating type exhibits every gradation that can result from these two varieties.

"We may therefore conclude that the present inhabitants of Hall Bay (opposite Yule Island) are a mixture of two races, one dark-skinned and crisp-haired, the other with lighter skin and smooth hair; and this is all that can be said from our present knowledge."

The light race-which we may call Papuan Mahorisare far more civilised than the dark Papuans. D'Albertis says of them :-

"The most perfect harmony seems to reign in families, and rare indeed are cases of quarrel among members of one household. They live in communities, sometimes of more than a thousand inhabitants, in well-built villages,

I "New Guinea: What I Did and What I Saw." By L. M. D'Albertis, Officer of the Order of the Crown of Italy, \&c., \&c. In two volumes. (London: Sampson Low, Marston, Searle and Rivington, I88c.) Continued from p. I 55 . 